\title{
Persistent Organic Pollutants in Human Milk from Central Italy: Levels and Time Trends
}

\author{
Cristiana Guerranti, Michela Palmieri, Michela Mariottini, and Silvano Ettore Focardi \\ Department of Environmental Sciences, University of Siena, Via P.A. Mattioli, 53100 Siena, Italy \\ Correspondence should be addressed to Cristiana Guerranti, guerranticri@unisi.it
}

Received 1 April 2011; Accepted 25 May 2011

Academic Editors: A. Botta and B. Zhou

Copyright (๑) 2011 Cristiana Guerranti et al. This is an open access article distributed under the Creative Commons Attribution License, which permits unrestricted use, distribution, and reproduction in any medium, provided the original work is properly cited.

Persistent organic pollutants (POPs) such as HCB, $p, p^{\prime}$-DDE, and PCBs were measured in Italian breast milk. This work is part of a study on human milk, adipose tissues, and food carried out in the same area over the last 20 years. The results showed the prevalence of $p, p^{\prime}$-DDE and PCBs over HCB. Comparison of our results with those of previous studies carried out in the same area showed that concentrations are decreasing. No statistically significant differences in organochlorine levels were found when the samples were divided into maternal age classes and into the categories "primiparae" and "multiparae". In order to quantify the amount of the molecules of interest transmitted by mother to child during breast feeding, we estimated the daily intake of each class of compounds: our results indicated that HCB and $p, p^{\prime}$-DDE were several times lower than the safety thresholds.

\section{Introduction}

The presence of organic pollutants in a mother's milk was first reported in 1951 by Laug et al. [1], who analyzed 32 samples of milk from women in Washington D.C. (USA) for the presence of the insecticide DDT and its metabolites. Jensen [2] subsequently reported the presence of PCBs in mother's milk (in 1966), and many other chemical contaminants have been detected in breast milk since then. Analyses of breast milk for environmental chemicals are of broad scientific interest, since human milk can be used as an indicator for the general level of contamination in a population, and thus it is useful to assess potential health risks associated with the intake of human milk. Large quantities of some chemicals may be transferred from mother to child through human milk [3]. In a study carried out in the Netherlands in 1999, it was estimated that breast feeding for 6 months accounts for between 12 and 14\% of exposure to some organochlorinated compounds in the first 25 years of life [4]. Various factors can increase the level of contamination in breast milk, including the mother's age (higher age is associated with a greater body burden of contaminants), the number of children (primiparae excrete more contaminants in their breast milk), the duration of previous breast feeding, and distance in time since this (in multiparae); other events that may have mobilized maternal fat deposits (such as weight loss treatments) and diet (in particular fish consumption) [5]. If we consider age as a predictive factor of plasma of PCB concentration, as age is correlated with the years of exposure to contaminated foods, we should also mention that although the presence of such molecules in food has decreased over the years, the half life of high chlorinated PCBs can vary from eight to over seventeen years [6]. In this study, the presence and levels of some classes of organochlorinated compounds was evaluated in samples of breast milk. In order to quantify the consumption by infants of the contaminants studied, their intake through breast milk was estimated. In fact, in many cases, human milk is the only food that newborns consume in the first months of life, such an analysis, therefore, makes it possible to estimate the intake of xenobiotics in a more simple and accurate manner than can be done in organisms with a more complex diet. This work is part of a long series of studies on human exposure to environmental contaminants in the Siena area. Organochlorines have been studied in human adipose tissue samples [7-11] and human milk [12]; organohalogen 
compounds have been determined in food and diet [1315], and perfluorinated compounds have been identified in human blood and serum [16].

The data acquired in this study have been compared with previous studies [12], in order to determine the temporal trend of contaminant concentrations in the breast milk of women residing in the study area. The results reported in this paper, together with those published previously [14] regarding the polybrominated diphenyl ethers (PBDEs) concentrations in the same samples, are intended to provide a detailed picture of contamination in breast milk in central Italy.

\section{Materials and Methods}

2.1. Sample Collection. Individual breast milk samples were obtained from women living in the Siena area, following the ethical standards and the approval of the Local Ethics Committee and the acquisition of informed consent. A total of 50 milk samples were collected about 8-10 days after delivery.

Information such as age, number of births, occupation, smoking, dietary habits, and so forth was recorded for all mothers. Participants in the study were on average $30.8 \pm$ 4.1 years of age and had lived in the area for at least 5 years. The human milk (about $50 \mathrm{~mL}$ ) was manually expressed into $100 \mathrm{~mL}$ contamination-free pots, and appropriate precautions (such as previous rinse with hexane) were taken to prevent the contamination of the samples. All samples were kept frozen at $-20^{\circ} \mathrm{C}$ until analysis.

2.2. Sample Analysis. OC pesticides and PCBs were extracted according to a wide tested method [15]. Milk samples (10$12 \mathrm{~g}$ ) were homogenized with sodium sulphate and soxhlet extracted with methylene chloride/hexane $(3: 1 \mathrm{v} / \mathrm{v})$ for 16 hours. After extraction, a portion of each extract was used for gravimetric determination of the total lipid content of the milk. The extract was rotary evaporated at $34^{\circ} \mathrm{C}$. A multilayer silica gel column was prepared by packing a glass column ( $20 \mathrm{~mm}$ internal diameter, i.d.) with a series of silica gel layers. The column was cleaned with $150 \mathrm{~mL}$ of hexane, then the samples were eluted with $200 \mathrm{~mL}$ of hexane and reduced to $1 \mathrm{~mL}$ using hexane. OC pesticides and PCBs were analyzed by gas chromatography using a Perkin Elmer Autosystem gas chromatograph fitted with a $63 \mathrm{Ni}$ electron capture detector (GC-ECD). The capillary column (SBP-5, Supelco) was $30 \mathrm{~m}$ long and $0.25 \mathrm{~mm}$ i.d., with a $0.25 \mu \mathrm{m}$ thick coating. Helium was used as the carrier gas. Injection was set at splitless mode, the injector temperature was $270^{\circ} \mathrm{C}$, and the column was programmed to be heated from $120^{\circ} \mathrm{C}$ to $280^{\circ} \mathrm{C}$ at $5^{\circ} \mathrm{C} / \mathrm{min}$, then maintained at $280^{\circ} \mathrm{C}$ for 10 minutes. The detector temperature was $300^{\circ} \mathrm{C}$, and the makeup gas was argon/methane (95/5). A mixture of the pesticide $\mathrm{HCB}, p, p^{\prime}$-DDE (the main DDT's metabolite) (Dr. Ehrenstorfer $\mathrm{GmbH}$ ), Aroclor 1260 and 1254 (Supelco), and mono-ortho PCBs (Dr. Ehrenstorfer $\mathrm{GmbH}$ ) were used as external standards and for calibration. Sample results were confirmed with a GCQ plus ion trap mass spectrometer (MS)

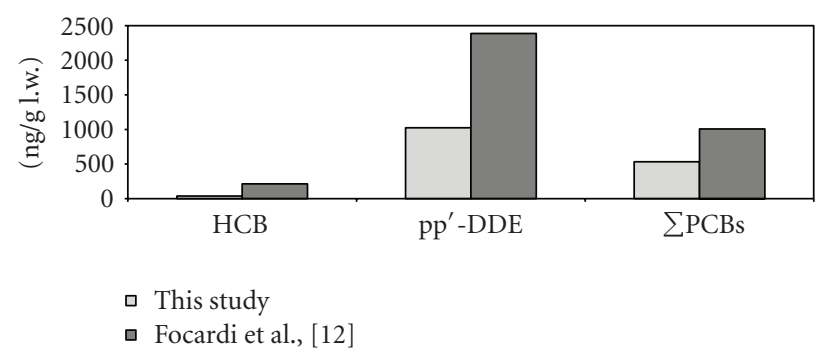

Figure 1: Time trend of OC concentrations (mean levels in ng/g l.w.) in human breast milk from central Italy.

from ThermoFinnigan in selected ion-monitoring mode (SIM). A trace gas chromatograph was equipped with an AS 2000 autosampler (ThermoFinnigan) and fitted with an Rtx5MS capillary column $(30 \mathrm{~m} \times 0.25 \mathrm{~mm}$ i.d., $0.25 \mu \mathrm{m})$ from Restek. GC conditions and information on target/qualifier ions are described elsewhere [17]. The concentrations of individually resolved peaks were summed to obtain total PCB concentrations, calculated on lipid weight (l.w.).

The procedures described above were checked for recoveries and reproducibility. Quality assurance for the measurement of OC pesticides and PCBs and for the technique was confirmed by analyzing certified reference materials provided by the Community Bureau of Reference (BCR) of the Commission of the European Communities, specifically, natural milk powder no. 187 for pesticides and no. 450 for PCBs. The results of two replicates were highly consistent with the certified values (mean errors: $4 \%$ for pesticides and $5 \%$ for PCBs). A blank prepared according to the same procedure used for the samples was included every five samples, and the results were blank corrected. The limit of detection (LOD), calculated as mean blank + 3SD, was $0.01 \mathrm{ng} / \mathrm{g}$ lipid for OC pesticides and PCBs. PCB-30 and PCB-209 were added to each sample as recovery standards and recoveries were ever higher than $88 \%$.

2.3. Statistical Analysis. Statistical analysis was performed using the Kruskal-Wallis one-way ANOVA by ranks, the Wilcoxon-Mann-Whitney test, and Spearman's correlation coefficient (rs). A probability level of less than 0.05 was considered significant. Statistical analysis, as well as the graph reported in Figures 1 and 2, was made using the programmes Microsoft Excel 2003 (Microsoft Corporation) and Statistica 7.1 (Statsoft Inc.), both for Windows XP.

\section{Results}

Fifty milk samples were analyzed by GC-ECD, and the results are shown in Table 1. $p, p^{\prime}$-DDE and PCBs were detected in almost all samples (95\% and $88 \%$ of samples, resp.), whereas just few samples (about 30\%) showed HCB in detectable concentrations. Of the OC pollutants, $p, p^{\prime}$-DDE prevailed, followed by PCBs and HCB. OC concentrations reported in this study were lower than those measured in milk samples collected previously from the same geographic area (the extraction method used was similar to that above described, 


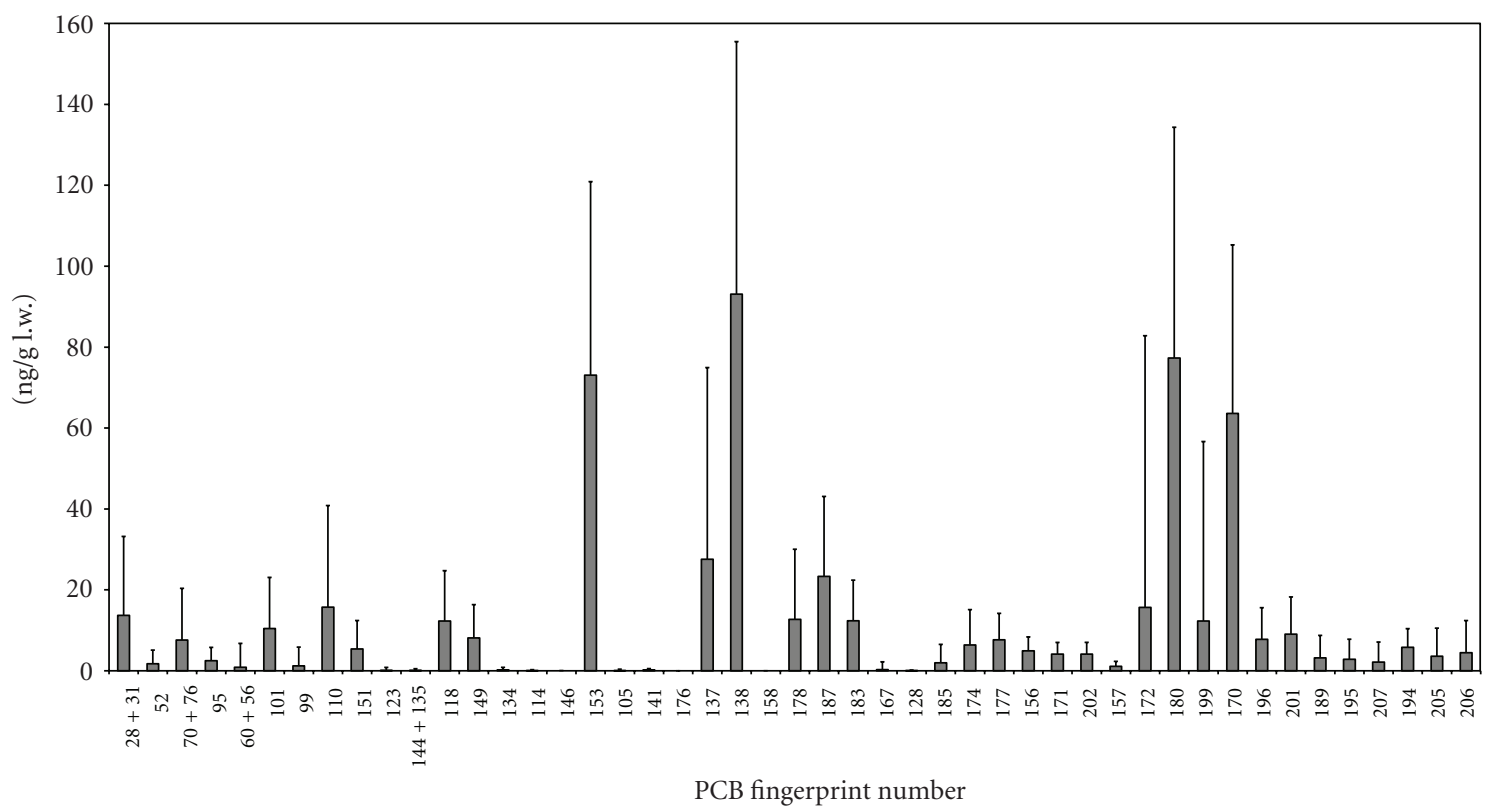

FIGURE 2: PCB Fingerprint (mean value \pm SD in ng/g l.w.) in breast milk samples.

and concentrations were determined by GC-ECD). Focardi et al. [12] reported mean concentrations of $p, p^{\prime}$-DDE, HCB, and PCBs in human milk of 2387, 214, and $1007 \mathrm{ng} / \mathrm{g}$ l.w., respectively (Figure 1 ).

Fifty-one congeners were singled out from the PCB residue (Figure 2). The most abundant congeners included PCB-138, PCB-153, PCB-180, PCB-170, and PCB-187. The order of prevalence of the congeners was PCB-153>PCB$180>$ PCB-138 $>$ PCB-170 $>$ PCB-118>PCB-187. Heptachlorobiphenyls accounted for 35\% of the total, followed by $33 \%$ for hexachlorobiphenyls and by $19 \%$ for pentachlorobiphenyls.

The samples analyzed were divided into age classes and according to the mother's number of deliveries (Table 2). The mean values of $p, p^{\prime}$-DDE, HCB, and $\Sigma \mathrm{PCB}$ were higher in the 35-40-year age class in relation to those of other classes, while there were no statistically significant differences in the organochlorinated compound concentrations between the categories "primiparae" and "multiparae".

All study participants reported low consumption of fish products, and the large majority declared to be no smoker; levels of OCs were not significantly associated with maternal age, potential occupational exposure, and particular dietary habits.

3.1. Estimated Contaminant Intake through Breast Milk Consumption. The data obtained from these analyses permitted us to estimate the quantities of the OCs studied that breastfeeding infants ingested through their diet. Considering an average daily intake of approximately $150 \mathrm{~g}$ of milk, a mean figure referring to the first week of life of a newborn baby [18], the daily intake was found to be $0.36 \mu \mathrm{g}$ of $\mathrm{HCB}, 8.61 \mu \mathrm{g}$ of $p, p^{\prime}-\mathrm{DDE}$, and $5.38 \mu \mathrm{g}$ of PCBs.
TABLE 1: HCB, $p, p^{\prime}$-DDE and PCB mean and median concentration (ng/g l.w.) from Italian breast milk $(n=50)$.

\begin{tabular}{lcc}
\hline ng/g b.l. & Mean (S.D.) & Median \\
\hline HCB & $38.66(46.40)$ & 21.09 \\
$p, p^{\prime}-\mathrm{DDE}$ & $1024(808.44)$ & 867.86 \\
$\sum$ PCB & $532.87(309.79)$ & 562.24 \\
\hline
\end{tabular}

\section{Discussion}

Apart from the excretion of OC pollutants through bile and urine, milk represents an alternative route of elimination in lactating animals, including humans. Variations in OC concentrations might be expected to occur in relation to factors such as the efficiency of absorption and excretion, the mother's age, and her nutritional and socioeconomic status. The prevalence of $p, p^{\prime}$-DDE over PCBs and HCB has previously been reported [11] in the adipose tissue of women living in Siena; the same study confirms also that HCB can be found in a limited fraction of the samples analyzed, probably due to a low use of this pesticide in the study area. $\mathrm{HCB}, p, p^{\prime}-$ DDE, and PCB levels were similar to concentrations detected in breast milk in the U.K. in the years 2001-2003 (range: ND-180; 22-1600; 26-530 ng/g l.w., resp.) [19], and in breast milk from Russia [20] in the year 2000 ( $p, p^{\prime}$-DDE 943 ng/g l.w and HCB $42.2 \mathrm{ng} / \mathrm{g}$ l.w.). Concerning PCBs, the results of this study are higher than those reported in Norwegian breast milk samples [21] collected in the years 2000-2001 (mean values 159-278 ng/g l.w.), in samples from Russia [20] in 2003 (median $283 \mathrm{ng} / \mathrm{g}$ l.w.), and for samples of breast milk from two large Chinese cities [22] (mean values $31 \mathrm{ng} / \mathrm{g}$ l.w. and $35 \mathrm{ng} / \mathrm{g}$ l.w.). In the latter study, however, the mean 
TABle 2: Mean (S.D.) and median concentrations (ng/g l.w.) of HCB, $p, p^{\prime}$-DDE and PCB in Italian breast milk samples divided into age classes and according to number of births.

\begin{tabular}{lccccccc}
\hline & & & \multicolumn{2}{c}{ Maternal age (years) } & \multicolumn{2}{c}{ Births } \\
ng/g l.w. & & $20-25$ & $25-30$ & $30-35$ & $35-40$ & Primiparae & Multiparae \\
& & $n=7$ & $n=17$ & $n=19$ & $n=7$ & $n=37$ & $n=13$ \\
\hline \multirow{2}{*}{ HCB } & Mean & $36.10(38.52)$ & $38.54(44.31)$ & $21.97(21.20)$ & $70.63(98.29)$ & $40.62(51.52)$ & $24.37(20.37)$ \\
& Median & 22.17 & 14.79 & 14.37 & 32.78 & 17.82 & 18.12 \\
\hline \multirow{2}{*}{$p, p^{\prime}$-DDE } & Mean & $870.80(815.28)$ & $717.08(402.17)$ & $1107.74(676.15)$ & $1548.45(1448.78)$ & $957.77(774.08)$ & $1149.69(836.40)$ \\
& Median & 468.87 & 639.29 & 1098.49 & 1341.02 & 853.02 & 1341.02 \\
\hline \multirow{2}{*}{$\sum$ PCB } & Mean & $535.13(239.88)$ & $490.84(316.96)$ & $573.16(374.78)$ & $573.46(418.84)$ & $582.46(299.04)$ & $541.66(308.63)$ \\
& Median & 628.37 & 416.30 & 585.37 & 591.30 & 601.76 & 585.37 \\
\hline
\end{tabular}

DDE values were twice as high as those reported in our data $(2,480-2,850 \mathrm{ng} / \mathrm{g}$ l.w. $)$.

Comparing our data with those previously obtained for the same area [12], a noticeable decline in OC contamination can be observed, with mean values resulting approximately $40 \%$ lower. Reduced contamination levels in human tissues in the years following antipollutant regulations have also been observed in other countries [22]. Kalantzi et al. [19] showed a decreasing trend in OC levels detected in breast milk (U.K.) since the sixties, probably as a consequence of bans imposed on the use of these contaminants. Dewailly et al. [23] described statistically significant decreases in HCB, DDT, and PCBs in human adipose tissue from Canada in the period 1969 to 1985 . Loganathan et al. [24] analyzed samples collected in Japan from 1928-1985, finding that the decline over the years seemed to correspond to the regulatory controls, especially regarding DDT levels.

PCB-138, PCB-153, PCB-180, PCB-170, PCB-137, and PCB-187 prevailed: these are the most common congeners in commercial mixtures and the environment [25]. The previous studies carried out in the Siena area $[8-11,13]$ confirm that the same group of congeners are the most common in human tissues and food; the difference from past studies is the prevalence in our samples of milk of PCB-138 rather than PCB-153. In fact, PCB-153 is the most common congener, due to its high persistence and low environmental degradability, as well as its characteristic of being difficult for organisms to metabolize [26, 27].

Hexa-CBs and hepta-CBs prevailed in Italian milk samples. They are the most common groups of isomers, partly because they have been widely used in commercial mixtures, such as Aroclor 1260 [28]. Concentrations of low chlorinated PCBs (tetra-CBs) in the fingerprints were much lower than those of other congeners. This finding may be linked to the fact that these PCBs are more easily metabolized and are less common in commercial mixtures.

The PCB congener prevalence obtained in this work are in accordance with those of other studies on breast milk [23, 29-31].

Age and exposure to persistent contaminants usually generate a positive correlation $[32,33]$, therefore, the lower the average age, the less the individual is likely to be exposed to contaminants. No significant correlation was found in this study between age and POP concentrations, neither were the differences between age classes statistically significant, even though the 35-40 age class showed the highest concentrations of OC compounds on average (Table 2).

Similarly, the study carried out on milk samples from Russia [34] also found no statistically significant difference in OC levels between primiparae and multiparae (Table 2), although the milk of primiparae should have higher OC concentrations than that of multiparae, as OCs accumulate throughout the years before pregnancy.

The FAO-WHO have defined acceptable intakes (known as tolerable daily intakes (TDI)) for a series of environmental contaminants. No TDI has been established for HCB, but an acceptable daily intake (ADI) of $0.6 \mu \mathrm{g} / \mathrm{kg}$ body weight (b.w.) is considered below any safe exposure threshold [35]. For compounds in the DDT group, an initial assessment established an ADI of $20 \mu \mathrm{g} / \mathrm{kg}$ b.w. [36], which was subsequently updated to a provisional TDI (PTDI) of $10 \mu \mathrm{g} / \mathrm{kg}$ b.w. [37]. There is no ADI for PCBs, nor a TDI specifically for them that is, for PCBs considered distinctly from dioxin and furan levels.

Considering a mean weight of breastfeeding babies of $3.5 \mathrm{~kg}[38,39]$, the calculated intake values are below the safety thresholds of $17 \%$ for HCB and $24.6 \%$ for $p, p^{\prime}$-DDE; therefore, the quantities of these OC pesticides consumed by breastfeeding babies in the Siena area are below the safety threshold for the health of infants whose diet consists exclusively of their mother's milk.

\section{Conclusions}

$p, p^{\prime}$-DDE and PCBs were detected in varying proportions in all samples, possibly due to the efficiency of absorption and excretion, and the mothers' age, nutritional, and socioeconomic status. Of the OC pollutants, $p, p^{\prime}$-DDE prevailed, followed by PCBs and HCB. The HCB, $p, p^{\prime}$-DDE, and PCB levels were similar to concentrations reported in milk samples from other parts of Europe. It emerged from a comparison with a previous study carried out on breast milk samples from the same area [12] that the presence of OCs has decreased between the 1980s and the present day, thus, confirming a European decline, corresponding to the regulatory controls applied. PCB-138 prevailed over PCB153 , in contrast to previous studies in the same area, while 
hexa-CBs and hepta-CBs were predominant, the latter have both been widely used in commercial mixtures, such as Aroclor 1260.

Age and exposure to persistent contaminants usually generate a positive correlation; the division of the samples into maternal age classes revealed that the class with the highest concentration was that of 35-40-year old women, although the difference was not statistically significant. Dividing the milk samples into two groups-from primiparae and from multiparae-did not reveal any clear differences in values between the two groups.

Exposure to xenobiotics can represent an important factor in determining increasingly common problems in children, such as immunological, neurological and behavioral, or developmental disorders. Moreover, epidemiological studies have suggested a relationship between cancer and exposure to POPs, some of which act as carcinogens [40]. However, it must also be emphasized that breastfeeding appears to have a protective effect against breast cancer in the mother [18]. Despite the presence of contaminants in the breast milk studied, the estimated intakes of OC pesticides were below safe threshold levels. These results and the clear decreasing trend that emerged from the comparison with a previous study carried out in the same area support breastfeeding, as there is a lack of evidence of risks due to the presence of contaminants in milk from this area, especially considering the psychological and nutritional importance of this practice. Nevertheless, preventive measures, such as food monitoring and dietary intake assessment, need to be adopted in order to reduce the body burden of OC pollutants and to ensure that the decrease in OC levels that began in the nineties can continue.

\section{Abbreviations}

DDT: dichlorodiphenyltrichloroethane

HCB: hexachlorobenzene

OCs: organochlorines

PBDEs: polybrominated diphenyl ethers

PCBs: polychlorinated biphenyls

$p, p^{\prime}$-DDE: dichlorodiphenyldichloroethylene.

\section{References}

[1] E. P. Laug, F. M. Kunze, and C. S. Prickett, "Occurrence of DDT in human fat and milk," American Medical Association Archives of Indication Hygiene, vol. 3, pp. 245-251, 1951.

[2] S. Jensen, "Report of a new chemical hazard," New Scientist, vol. 32, p. 612, 1966.

[3] P. J. Landrigan, B. Sonawane, D. Mattison, M. McCally, and A. Garg, "Chemical contaminants in breast milk and their impacts on children's health: an overview," Environmental Health Perspectives, vol. 110, no. 6, pp. A313-A315, 2002.

[4] S. Patandin, P. C. Dagnelie, P. G. H. Mulder et al., "Dietary exposure to polychlorinated biphenyls and dioxins from infancy until adulthood: a comparison between breastfeeding, toddler, and long-term exposure," Environmental Health Perspectives, vol. 107, no. 1, pp. 45-51, 1999.
[5] C. A. Harris, M. W. Woolridge, and A. W. M. Hay, "Factors affecting the transfer of organochlorine pesticide residues to breastmilk," Chemosphere, vol. 43, no. 2, pp. 243-256, 2001.

[6] M. P. Longnecker, W. J. Rogan, and G. Lucier, "The human health effects of DDT (dichlorodiphenyl-trichloroethane) and PCBs (polychlorinated biphenyls) and an overview of organochlorines in public health," Annual Review of Public Health, vol. 18, pp. 211-244, 1997.

[7] S. Focardi, C. Fossi, C. Leonzio, and R. Romei, "PCB congeners, hexachlorobenzene, and organochlorine insectidices in human fat in Italy," Bulletin of Environmental Contamination and Toxicology, vol. 36, no. 5, pp. 644-650, 1986.

[8] S. Focardi and R. Romei, "Fingerprint of polychlorinated biphenyl congeners in samples of human subcutaneous adipose tissue," Chemosphere, vol. 16, no. 10-12, pp. 2315-2320, 1987.

[9] S. Corsolini, S. Focardi, K. Kannan, S. Tanabe, and R. Tatsukawa, "Isomer-specific analysis of polychlorinated biphenyls and 2,3,7,8- tetrachlorodibenzo-p-dioxin equivalents (TEQs) in red fox and human adipose tissue from central Italy," Archives of Environmental Contamination and Toxicology, vol. 29, no. 1, pp. 61-68, 1995.

[10] M. Mariottini, S. Aurigi, and S. Focardi, "Congener profile and toxicity assessment of polychlorinated biphenyls in human adipose tissue of Italians and Chileans," Microchemical Journal, vol. 67, no. 1-3, pp. 63-71, 2000.

[11] M. Mariottini, C. Guerranti, S. Aurigi, I. Corsi, and S. Focardi, "Pesticides and polychlorinated biphenyl residues in human adipose tissue," Bulletin of Environmental Contamination and Toxicology, vol. 68, no. 1, pp. 72-78, 2002.

[12] S. Focardi, C. Fossi, and E. Fossi, "Livelli di pesticidi clorurati e policlorobifenili nel latte umano," Rivista Italiana di Pediatria, vol. 10, pp. 286-290, 1984 (Italian).

[13] C. Guerranti, Indagine sulla presenza di composti organoalogenati in prodotti alimentari e nella dieta della popolazione dell'area senese, Ph.D. dissertation, University of Siena, Siena, Italy, 2007.

[14] C. Guerranti, M. Mariottini, and S. E. Focardi, "Dietary exposure to PBDEs and levels in breast milk of women living in central Italy," Organohalogen Compound, vol. 70, 2008.

[15] C. Guerranti, G. Perra, M. Renzi, S. Focardi, and S. Focardi, "Chlorinated contaminants in extra-virgin olive oil from central Italy," Journal of Food Lipids, vol. 15, no. 2, pp. 190197, 2008.

[16] S. Mangani, Composti perfluorurati in campioni di sangue e siero di donne affette da endometriosi, Degree dissertation, University of Siena, Siena, Italy, 2007.

[17] I. Corsi, M. Mariottini, A. Badesso et al., "Contamination and sub-lethal toxicological effects of persistent organic pollutants in the European eel (Anguilla anguilla) in the Orbetello lagoon (Tuscany, Italy)," Hydrobiologia, vol. 550, no. 1, pp. 237-249, 2005.

[18] J. Riordan, K. Gill-Hopple, and J. Angeron, "Indicators of effective breastfeeding and estimates of breast milk intake," Journal of Human Lactation, vol. 21, no. 4, pp. 406-412, 2005.

[19] O. I. Kalantzi, F. L. Martin, G. O. Thomas et al., "Different levels of polybrominated diphenyl ethers (PBDEs) and chlorinated compounds in breast milk from two U.K. regions," Environmental Health Perspectives, vol. 112, no. 10, pp. 10851091, 2004.

[20] A. Egorov, G. Mikhailov, and L. Altshul, "Fish consumption and breast milk concentrations of PCBs and chlorinated pesticides in the Astrakhan region, Russia," Organohalogen Compound, vol. 64, pp. 91-94, 2003. 
[21] G. Becher, L. Småstuen Haug, T. Nicolaysen, A. Polder, and J. Utne Skaare, "Temporal and spatial trends of PCDDs/PCDFs and PCBs in Norwegian breast milk-results from three rounds of who co-ordinated studies," Organohalogen Compound, vol. 56, pp. 325-328, 2002.

[22] C. K. C. Wong, K. M. Leung, B. H. T. Poon, C. Y. Lan, and M. H. Wong, "Organochlorine hydrocarbons in human breast milk collected in Hong Kong and Guangzhou," Archives of Environmental Contamination and Toxicology, vol. 43, no. 3, pp. 364-372, 2002.

[23] E. Dewailly, J. P. Weber, S. Gingras, and C. Laliberte, "Coplanar PCBs in human milk in the province of Quebec, Canada: are they more toxic than dioxin for breast fed infants?" Chemosphere, vol. 23, pp. 1831-1835, 1991.

[24] B. G. Loganathan, S. Tanabe, Y. Hidaka, M. Kawano, H. Hidaka, and R. Tatsukawa, "Temporal trends of persistent organochlorine residues in human adipose tissue from Japan, 1928-1985," Environmental Pollution, vol. 81, no. 1, pp. 31-39, 1993.

[25] V. A. McFarland and J. U. Clarke, "Environmental occurrence, abundance, and potential toxicity of polychlorinated biphenyl congeners: considerations for a congener-specific analysis," Environmental Health Perspectives, vol. 81, pp. 225-239, 1989.

[26] S. Safe, "Toxicology, structure-function relationship, and human and environmental health impacts of polychlorinated biphenyls: progress and problems," Environmental Health Perspectives, vol. 100, pp. 259-268, 1993.

[27] M. Van Den Berg, L. Birnbaum, A. T. C. Bosveld et al., "Toxic equivalency factors (TEFs) for PCBs, PCDDs, PCDFs for humans and wildlife," Environmental Health Perspectives, vol. 106, no. 12, pp. 775-792, 1998.

[28] WHO, "Polychlorinated biphenyls and terphenyls," World Health Organisation Geneva, vol. 42-43, pp. 65-70, 1976.

[29] D. Davies and J. Mes, "Comparison of the residue levels of some organochlorine compounds in breast milk of the general and indigenous Canadian populations," Bulletin of Environmental Contamination and Toxicology, vol. 39, no. 5, pp. 743-749, 1987.

[30] A. A. Jensen, "Polychlorobiphenyls (PCBs), polychlorodibenzo-p-dioxins (PCDDs) and polychlorodibenzofurans (PCDFs) in human milk, blood and adipose tissue," Science of the Total Environment, vol. 64, no. 3, pp. 259-293, 1987.

[31] J. Mes and L. Marchand, "Comparison of some specific PCB isomers in human and monkey milk," Bulletin of Environmental Contamination and Toxicology, vol. 39, pp. 736-742, 1987.

[32] K. Teschke, S. J. Kelly, M. Wiens et al., "Background levels of PCBs in residents of British Columbia, Canada," Bulletin of Environmental Contamination and Toxicology, vol. 50, no. 6, pp. 842-851, 1993.

[33] R. Duarte-Davidson, S. C. Wilson, and K. C. Jones, "PCBs and other organochlorines in human tissue samples from the Welsh population: I-adipose," Environmental Pollution, vol. 84, no. 1, pp. 69-77, 1994.

[34] O. V. Tsydenova, A. Sudaryanto, N. Kajiwara, T. Kunisue, V. B. Batoev, and S. Tanabe, "Organohalogen compounds in human breast milk from Republic of Buryatia, Russia," Environmental Pollution, vol. 146, no. 1, pp. 225-232, 2007.

[35] FAO-WHO, "Joint Meeting on Pesticides Residues. Hexachlorobenzene (HCB). WHO Pesticide Residues Series 3," 1973, http://www.inchem.org/documents/jmpr/jmpmono /v073pr16.htm.

[36] FAO-WHO, "Pesticide residues in food-1984 evaluations, Plant Production and Protection," vol. 67. Rome, Italy, 1985.
[37] FAO-WHO, "Pesticide residues in food-2000. Evaluationspart II-Toxicology. Joint FAO-WHO Meeting on Pesticide Residues," 2001, http://www.inchem.org/documents/ jmpr/jmpmono/v00pr03.htm.

[38] T. Yakushiji, I. Watanabe, K. Kuwabara, S. Yoshida, K. Kojama, and N. Kunita, "Levels of polychlorinated biphenyls (PCBs) and organochlorine pesticides in human milk collected in OsakaPrefecture from 1972 to 1977," International Archives of Occupational and Environmental Health, vol. 45, pp. 567-571, 1979.

[39] J. T. Wilson, Farmaci e Allattamento, Il Pensiero Scientifico Editore, Rome, Italy, 1978.

[40] K. J. Aronson, A. B. Miller, C. G. Wooleott et al., "Breast adipose tissue concentrations of polychlorinated biphenyls and other organochlorines and breast cancer risk," Cancer Epidemiology Biomarkers and Prevention, vol. 9, no. 1, pp. 5563, 2000. 

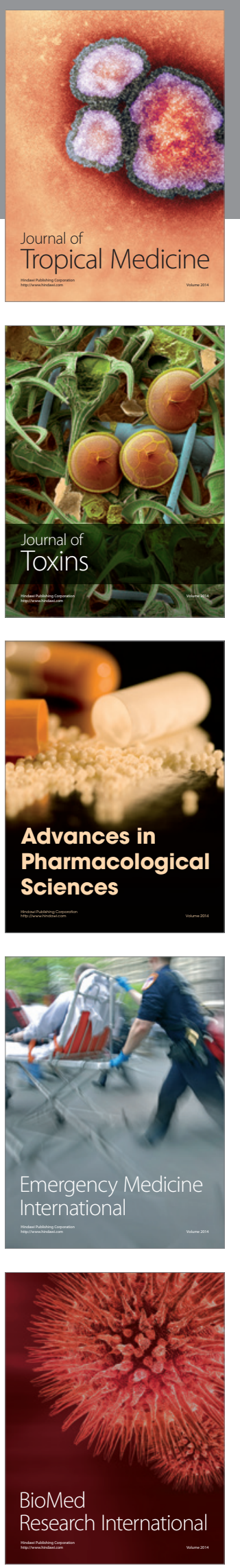
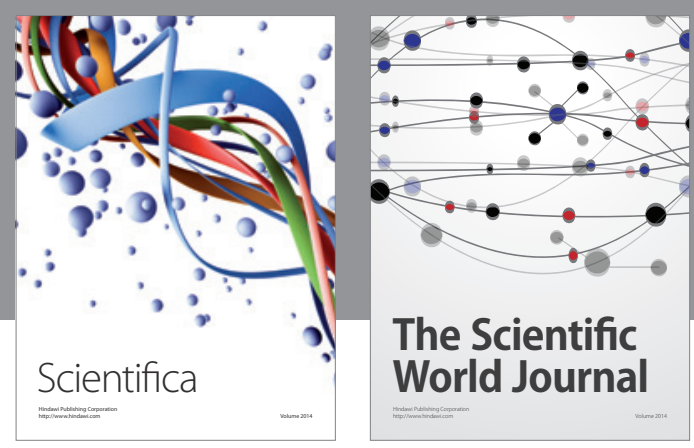

The Scientific World Journal
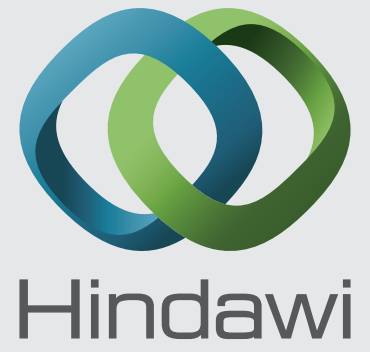

Submit your manuscripts at

http://www.hindawi.com
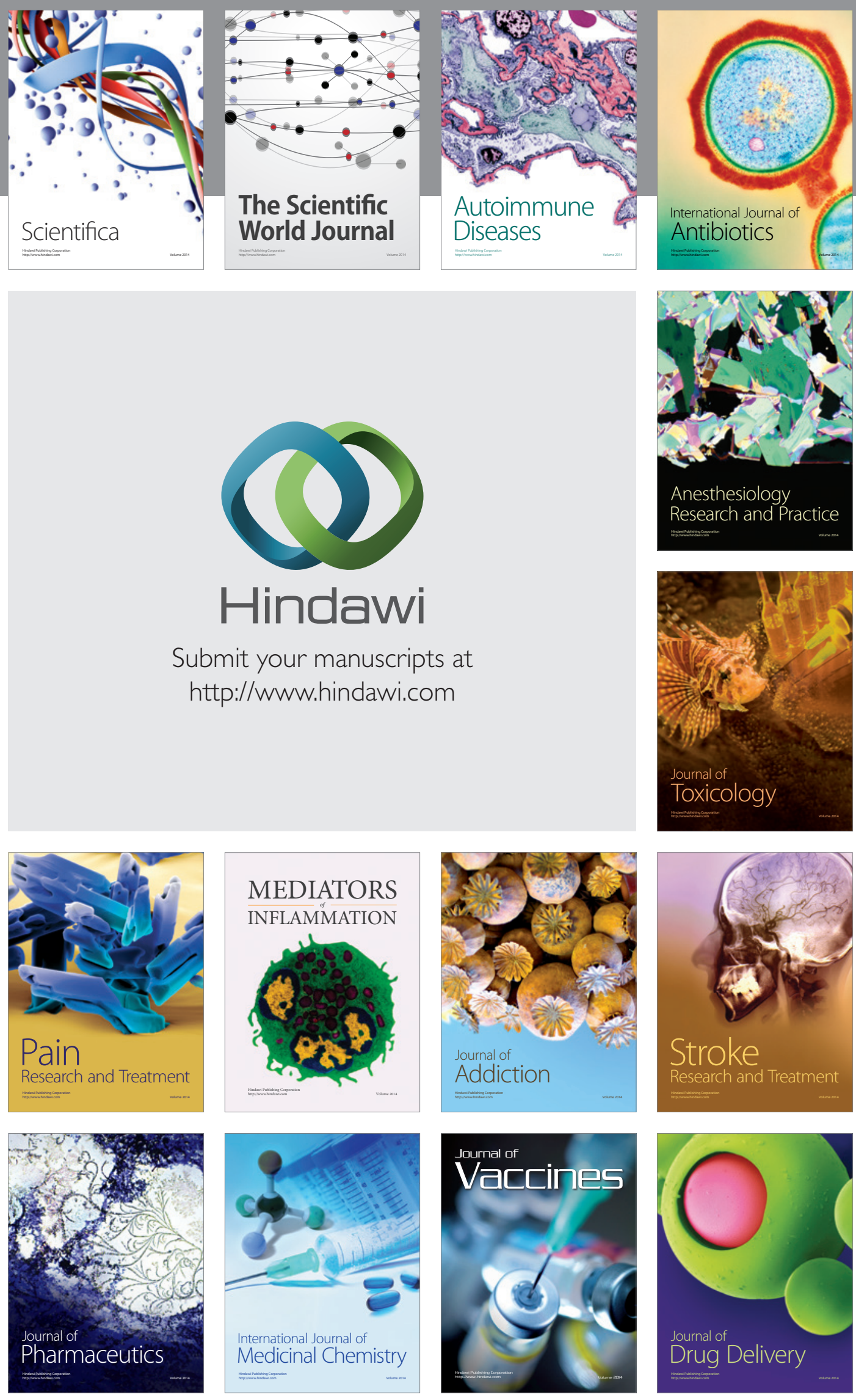